\title{
Correction to: Leadership, the American Academy of Management, and President Trump's Travel Ban: A Case Study in Moral Imagination
}

\author{
Haridimos Tsoukas ${ }^{1,2}$
}

Published online: 28 June 2019

(c) The Author(s) 2019

\section{Correction to: Journal of Business Ethics https://doi.org/10.1007/s10551-018-3979-y}

This notice serves to identify and correct the following inaccuracies in article Tsoukas (2018) Leadership, the Academy of Management, and President Trump's Travel Ban: A Case Study in Moral Imagination published online on 26 July 2018.

The article referred to a number of dates and external sources. However, it described some of these dates incorrectly and omitted some linked sources. The original and corrected timelines are shown here:

Original timeline (errors marked out)

Tsoukas, 2018, p. 2

On January 27th President Trump signed an Executive order... (For the full text, see https://www.whitehouse.gov/presidential-actions/ executive-order-protecting-nation-foreign-terrorist-entry-united-state $\mathrm{s} / \ldots)$

Tsoukas, 2018, p. 3

On 1 Febrtary 2017, the then AOM President, Professor Anita McGahan, made an announcement to its members, explaining the position of the Academy (See http://aom.org/About-AOM/Gover nance/AOM-President-s-Message-on-Executive-Order-on-Immig ration-Refugees.aspx)
Corrected timeline (additions in bold)

Tsoukas, 2018, p. 2

On January 27th, 2017 President Trump signed an Executive order...

(For the full text, see https://www.whitehouse.gov/presidential-actio ns/executive-order-protecting-nation-foreign-terrorist-entry-unite d-states/...)

On 31 January 2017, the then AOM President, Professor Anita McGahan, made an announcement to its members, explaining the position of the Academy (See http://aom.org/About-AOM/Governance/AOMPresident-s-Message-on-Executive-Order-on-Immigration-Refugees. aspx)

The following date and sources were omitted.

On 10 February 2017 Professor Anita McGahan in her role as President of the AOM posted on the AOM website and distributed by email to all AOM members an announcement regarding a policy amendment to come into effect 90 days hence following a process of internal consultation (See http://aom.informz.net/infor mzdataservice/onlineversion/ind/bWFpbGluZ2luc3RhbmNlaWQ9N Tg3Njc4OSZzdWJzY3JpYmVyaWQ9NzY3OTg3MjIx). Following the consultation process an amended policy came into effect on 21 April 2017 (See http://aom.org/FAQExecutiveOrder.aspx)

The original article can be found online at https://doi.org/10.1007/ s10551-018-3979-y.

\footnotetext{
Haridimos Tsoukas

htsoukas@ucy.ac.cy; Hari.Tsoukas@wbs.ac.uk

1 University of Cyprus, Nicosia, Cyprus

2 University of Warwick, Coventry, UK
} 
Tsoukas, 2018, p. 1

Later, in April 2017, following several reactions by members to the Academy's initial response, and instigated by Professor McGahan as well as past Aeademy Presidents, AOM amended its policy on taking political stands. See https://aom.org/About-AOM/Governance /AOM-Policy-on-Taking-Stands.aspx)

Tsoukas, 2018, p. 1

The shift was completed in October 2017, when the new AOM President Professor Mary Ann Glynn wrote officially to President Trump... (See http://aom.org/uploadedFiles/About_AOM/Gover nance/White_House_Letter_10-16-17_FINAL.pdf)
Later, on 10 February 2017, following several reactions by members to the Academy's initial response, and instigated by Professor McGahan on the earliest possible date for a Board meeting given the 7-day requirement for notice after Executive Committee approval, AOM amended its policy on taking political stands. The recommend amendment was accompanied by an embargo on its implementation for 90 days to allow deliberation on its implementation. The recommendations were adopted and policy was amended by the Board of Governors on 21st April 2017. See https://aom.org/About-AOM/Governance/AOMPolicy-on-Taking-Stands.aspx and https://aom.org/FAQExecutiveOrder.aspx)

The shift was completed in October 2017, when, because she had become the new AOM President, Professor Mary Ann Glynn wrote officially to President Trump... (See http://aom.org/uploadedFiles/ About_AOM/Governance/White_House_Letter_10-16-17_FINAL.pdf)

The following additional corrections are being made:

Original text (errors marked out)

Title:

Leadership, the Ameriean Academy of Management, and President Trump's Travel Ban: A Case Study in Moral Imagination

Tsoukas, 2018, p. 1:

However, the stand of the Ameriean Academy of Management (hereafter: $\mathrm{AOM}$ ) was more complicated.

Tsoukas, 2018, p. 3:

In other words, the AOM President's initial response to the travel ban amounts to the following (my rendition): "in the aftermath of the travel ban, we as AOM will do anything technically possible to facilitate our members' participation in the Annual Meeting in Atlanta. Beyond that, however, irrespectively of what each of of tw individually feels about it, and despite the travel ban opposing our scholarly values, there is nothing else really we, as the current AOM leaders, can do, since our policies restrict officers from taking a stand on any political issue in the name of AOM':

Tsoukas, 2018, p. 5:

Moreover, after this ineident, she was the driving force for making the case that AOM should reconsider its policy on political speech (which it did at its Board of Governors' regular meeting on Aprit 21st 2017).

Tsoukas, 2018, p. 9:

Although, judged by the criterion of disclosive moral imagination, the AOM President shows a restricted understanding of leadership agency, the picture is more complex, since she stbsequenty took the lead to change the organization from within, namely change AOM's policy on taking political stands.

Tsoukas, 2018, p. 9:

AOM President MeGahan seores low in moral imagination as diselosive power and high in moral imagination as ineremental foree.
Corrected text (additions in bold)

Leadership, the Academy of Management, and President Trump's Travel Ban: A Case Study in Moral Imagination

Tsoukas, 2018, p. 1:

However, the stand of the Academy of Management (hereafter: AOM) was more complicated.

In other words, the AOM leadership's initial response to the travel ban can be seen to amount to the following: In the aftermath of the travel ban, the AOM leadership were prepared to do anything technically possible to facilitate their members' participation in the Annual Meeting in Atlanta. Beyond that, however, irrespectively of what any individual AOM leader might have felt about it, and despite the travel ban opposing AOM's purported scholarly values, there seemed to be nothing else really the extant AOM leaders, could do for the time being since the AOM extant policies restricted officers from taking a stand on any political issue in the name of AOM

Moreover, it should be noted that she had been the driving force for making the case that AOM should reconsider its policy on political speech both prior to and after the travel ban (which it amended on February 10th 2017 and adopted at the AOM Board of Governors' regular meeting on April 21st 2017).

Although, judged by the criterion of disclosive moral imagination, the AOM President shows a restricted understanding of leadership agency, the picture is more complex, since she took the lead to change the organization from within, namely change AOM's policy on taking political stands.

(Text deleted, no replacement text.)

Publisher's Note Springer Nature remains neutral with regard to jurisdictional claims in published maps and institutional affiliations. 